\title{
Los Besos de Juan Segundo (traducción española, inédita, de Juan Gualberto González)
}

VICTORIANO PUNZANO Biblioteca Menéndez Pelayo, Santander

\section{El manuscrito}

Joannis Secvndi / Poetae Haigiensis / Basia 19. / Los 19 Besos de Jvan Segvndo / Poeta Holandés. / Bruselas 1833. Así reza la portada de un manuscrito encontrado recientemente en la Biblioteca de Menéndez Pelayo de Santander. Su letra es de la segunda mitad del siglo XIX; tiene 1 hoja y 82 páginas, de $210 \times 155$ y caja de escritura variable. Su contenido es: I. Noticias de la vida y escritos de Juan Segundo, pp. 1-9; II. El texto latino de los Besos en una página, y la traducción española en la otra, pp. 10-78; III. Finalmente, sendas versiones de los besos $1 .^{\circ}$ y $3 .^{\circ}$, y variantes de otros, pp. 79-82.

\section{El traductor}

Por ninguna parte del manuscrito aparece el nombre del traductor; sin embargo, no fue difícil averiguar su identidad. En la Biblioteca de Traductores Españoles, II, p. 153, edición nacional, de Marcelino Menéndez Pelayo, encontramos la respuesta dentro del apartado dedicado a Juan Gualberto González, noti- 
cia que, a su vez, él toma del Cathalogus librorum del Marqués de Morante, VIII, pp. 482-93, quien también en un folleto titulado Biografía de Juan Segundo, p. 16, afirma: «Nuestro sabio D. Juan Gualberto González, hablando de los Besos de Juan Segundo, en un manuscrito suyo inédito que poseemos».

\section{El texto}

El Marqués de Morante dio a conocer del manuscrito de Juan G. González solamente parte del prólogo y la traducción de los besos $1 .^{\circ}$, en dos versiones, $6 .^{\circ}, 7 .^{\circ}$ y $13 .^{\circ}$; este último Menéndez Pelayo dice ser el $12 .^{\circ}$. A la vista del texto, que Gómez de la Cortina nos facilita en su Biografía de Juan Segundo, lo primero que se aprecia es que no es coincidente con el que nosotros presentamos. Las variantes entre ambos textos nos parecen suficientemente significativas como para ofrecer algunas muestras, aunque, por lo limitado del espacio de un artículo, transcribiremos únicamente las del prólogo dejando para el pie de página la indicación de las correspondientes a la traducción.

Gómez de la Cortina omite los tres primeros párrafos de la «Noticia y escritos de Juan Segundo», comenzando en el cuarto:

\section{Gómez de la Cortina}

Entre sus producciones obtienen la preferencia los XIX Besos. El autor de la Biblioteca de un hombre de gusto los califica diciendo que son como los primeros ímpetus de una alma llena de ternura, voluptuosa y apasionada. En efecto, sus imágenes son naturales, y sus descripciones, en que se ajustó más que Catulo (lo cual no es mucho decir) a las leyes de la honestidad, tanto más interesantes cuanto son la expresión sencilla y verdadera de una alma que sólo respira amores.

\section{Nuestro manuscrito}

Entre sus producciones obtiene la preferencia Los 19 Besos. El autor de la Biblioteca de un hombre de gusto los califica diciendo que son como los primeros ímpetus de un alma llena de ternura, voluptuosa y apasionada. En efecto, sus imágenes son animadas, naturales y vivas; y sus descripciones, en que se ajustó más que Catulo (no es mucho decir) a las leyes de la honestidad, tanto más interesantes cuanto son la expresión sencilla y verdadera de su alma que sólo respira amores. 
El párrafo quinto del Marqués de Morante, que se refiere a la inexistencia de traducciones castellanas de los Besos, viene en nuestro texto como nota del «copiante» al pie de página. También aquí continúan las variantes, aunque de menor entidad en esta ocasión.

Después, en el siguiente, el texto de Gómez de la Cortina forma un solo cuerpo con el quinto párrafo de nuestro manuscrito, pero con variantes:

\section{Gómez de la Cortina}

En francés hay dos traducciones en prosa, de las cuales se dice que la primera hubiera sido más digna del original si a las bellas dotes de una prosa elegante y sonora acompañasen aquella sensibilidad y viveza que tanto resaltan en el modelo; y que la imitación que hizo en verso Dorat es, como la mayor parte de sus obras, más amanerada que natural, observándose que las imágenes más patéticas del amor se encuentran de ordinario como ahogadas en el exceso de los adornos y de los conceptos alambicados.

\section{Nuestro manuscrito}

No tenemos traducción alguna en castellano. En francés hay dos en prosa, de las cuales se dice que la primera hubiera sido más digna del original, si a las buenas dotes de una prosa elegante y armoniosa acompañasen aquella sensibilidad y belleza que tanto resaltan en el modelo. Y que la imitación que hizo Dorat en verso es como la mayor parte de sus obras más amanerada que natural, observándose que las imágenes más patéticas del amor se encuentran de ordinario como ahogadas en el exceso de los adornos y los conceptos alambicados.

Y al final, Gómez de la Cortina introduce un párrafo del que nuestro texto carece:

\section{Gómėz de la Cortina}

$\mathrm{Y}$ espero que los inteligentes han de aprobar estas licencias (que no son en gran número), y más no tra-

\section{Nuestro manuscrito}

$\mathrm{Y}$ espero que los inteligentes han de apreciar estas licencias, que no son en gran número. Y para los que 
tándose de un texto tan venerado como el de Virgilio y Horacio, en cuyas traducciones, aun las del mismo Fray Luis de León, se disgustan sus aficionados cuando sobran o faltan pensamientos, o los hallan desleídos o expresados de manera diferente. El texto de Juan Segundo no se halla en este caso; y para los que no gustan (ni yo tampoco) de tanto besuqueo ni de tanta desnudez, hubiera yo trabajado como al final del beso XII en disfrazar de metáforas o con otras imágenes, principalmente el V, X y XVI, si no temiese desfigurarlos del todo, $y$ si no bastasen a disculparme los ejemplos de otros Poetas originales, imitadores y traductores, con fama de castos y de filósofos, que se leen y andan con aplauso y recomendación de modelos en manos de la juventud estudiosa. Que bien pudiera yo decir: «j'ai vu les mours de mon temps, et j'ai traduit les Baisers de Jean Second». no gustan (ni yo tampoco) de tanto besuqueo, ni de tanta desnudez, hubiera yo trabajado como al final del Beso 12, en disfrazar con metáforas, o con otras imágenes, principalmente el $5 .^{\circ}$, el $10 .^{\circ}$ y el $16 .^{\circ} \mathrm{si}$ no temiera desfigurarlos del todo; y si no bastasen a disculparme los ejemplos de otros poetas originales, imitadores y traductores, con fama de castos y de filósofos, que se leen $\mathrm{y}$ andan con aplauso y recomendación de modelos en manos de la juventud estudiosa. Que bien pudiera yo también decir: «J'ai vu les mœurs de mon temps, et j'ai traduit les Baisers de Jean Second».

A la vista de las variantes apuntadas, que no son todas, se desprende que Gómez de la Cortina no parece que manejaba el «manuscrito suyo / de Juan Gualberto González / inédito», sino también una copia. Por otra parte, el texto del Cathalogus librorum, que transcribe Menéndez Pelayo, y el que leemos en el folleto Biografía de Juan Segundo no son coincidentes; al contrario, presentan variantes tales que nos hacen pensar que el Marqués de Morante usó de copias distintas en cada caso. 


\section{Traducciones españolas de los «Besos»}

Cuando Menéndez Pelayo escribe la reseña sobre Juan G. González, 14 de marzo de 1876, se habían publicado ya dos traducciones; una, la impresa en Córdoba, en 1834, de la cual da noticia el propio Juan Gualberto, según el Marqués de Morante, o el copiante, según el manuscrito de la Biblioteca de Menéndez Pelayo, cuya portada reza así: Los besos. Juan Segón, traducido del latín. Es de autor anónimo. La otra es del Padre Arolas en: Poesías de D. Juan Arolas, III vols. (Valencia, Imprenta de Monpié, 1842), III, pp. 1-41. Ambas en prosa.

José R. Lomba y Pedraja en El P. Arolas, su vida y sus versos (Madrid, 1898), p. 172, dice que «la traducción de Arolas no lo es de los versos latinos de aquél [de Juan Segundo], sino de la versión francesa, en prosa, de Mirabeau. A ésta la sigue a la letra, conviniendo hasta en la sustitución del nombre de Neera por el de Sofía», como se puede apreciar en el beso $4 .^{\circ}$ cuya traducción ofrecemos:

No da besos mi querida Sofía, que da néctar; exhala olor delicioso de nardo, de tomillo, de cinamomo y de miel semejante a aquella que las abejas cogen en el monte Himetto o en los rosales de los cecropios campos, depositadas en pequeñas celdillas de su gruta de mimbres. ¡Sofía! Tu aliento respira los perfumes más suaves... si yo saboreo largo tiempo tus caricias, si yo me enajeno con tus besos, ellos me harán inmortal y partiré con los Dioses la ambrosía de que se alimentan... Pero guarda tus favores, imi Sofía!... Niega a tu amante los voluptuosos besos, o alcanza como yo la inmortalidad... Yo no quiero, sin ti, ser admitido en los banquetes de los Dioses... No... Sin ti no admitiría yo el trono del mismo Júpiter, cuando todos los dioses coligados contra él me ofreciesen el trono del universo.

Foulché-Delbosc publicó en la Revue Hispanique, I (1894), p. 74 y ss., «Los Besos de amor de Juan Segundo, traducidos por el Dr. D. Juan Meléndez Valdés»; sin embargo, y a pesar del título, como el propio Foulché indica, ni es una traducción, ni tan siquiera una imitación, aunque, como apunta Juan Gualberto González, o el copiante, «hay imitaciones y pensamientos tomados del autor, como pueden verse en Meléndez las odas, 23, 31 y 
51 , tom. $1 .^{\circ}$ (Madrid, 1820) en las cuales se ven reproducidos el plan y las ideas de los Besos $4 .^{\circ}, 11 .^{\circ}$ y $\left.19 .^{\circ}\right)$.

Después del Padre Arolas no encontramos durante el siglo XIX publicación alguna de nueva traducción española de los $B e$ sos; ' posiblemente pesara en nuestros humanistas aquello que Menéndez Pelayo dijera sobre Juan Gualberto González: «Existen además dos traducciones suyas, que no se atrevió a dar a la estampa y que, por las noticias y trozos que de ellas conocemos, en nada desmerecerían de las de Horacio, Virgilio, Calpurnio y Nemesiano. ¡Lástima que sean de composiciones un tanto escabrosas y no muy propias para ser impresas en lengua vulgar! Una edición, no obstante, de limitados ejemplares, una copia en la Biblioteca Nacional bastarían a poner tales versiones al alcance de los eruditos y humanistas, sin exponerlas a los vientos de la publicidad. En último caso debieran publicarse expurgadas, medio no muy aceptable, pero preferible siempre a la completa pérdida y olvido de estos manuscritos» (Biblioteca de Traductores Españoles, II, p. 151).

A principios de nuestro siglo podemos ya leer una versión poética del poema de Juan Segundo, aunque su autor se cuidó muy bien de no darla a la luz pública, siguiendo seguramente la tendencia escrupulosa y rigorista de la moral al uso de los tiempos de Menéndez Pelayo. Fue publicada por, los herederos, y bajo seudónimo. Se trata de El poema de los besos por Juan Segundo. Traducción de Luis de Avilés (Madrid, Tip. Artística, 1914). Luis Avilés no es otro que Carlos Fernández Shaw, quien se dirige Al lector así: «No me extrañaría que, hasta el momento presente, desconocieras al autor de Los besos; que ignoraras, como yo ignoré durante muchos años, que existió ese poeta, flor de un día, sólo conocido, en verdad, aquende el Pirineo, por las personas muy versadas en asuntos literarios». Fernández Shaw prosigue su prólogo con unas breves noticias biográficas de Juan Segundo e indica que sus fuentes proceden de «una disertación latina de Pedro Bosch, profesor de Literatura en la Academia de Deventer, que publicó en Leyden las obras de Juan Segundo, allá por el año 1820 , y el prólogo que figura en una edición francesa 
de Los besos, dada a luz por la Librería de los Bibliófilos de París, en 1872».

La traducción de Carlos F. Shaw sí tiene presente el original latino de los Besos, apartándose de este modo de la versión anónima de Córdoba y de la del P. Arolas, aunque también traduce el nombre de Neera por el de Laura, atendiendo indudablemente a razones métricas, como se aprecia en el beso $4 .^{\circ}$ :

No; no son besos los que da mi Laura.

Néctar son. En su aliento perfumado

se gustan los finísimos aromas

de la mirra, del nardo y cinamomo.

Son una miel tan sólo comparable

a la que liban múltiples abejas

en las dulces vertientes del Himeto

o en las rosas del Ática, - tan ricas

en pompa, y en perfumes y en colores-

por dejarlas después, unas con otras,

en las celdillas de la cera virgen.

Si yo gustara mucho de sus besos de pronto en inmortal me trocaría. Me alimentara con manjar de dioses. Pero no, Laura, no; yo no quisiera merecer tal favor, si tú no fueres inmortal a tu vez. Jamás, oh Laura, sin que te mire junto a mí, dichosa, querré gozar de célicos banquetes; aunque diosas y dioses, destronando a Júpiter olímpico, me ofrezcan el cetro poderoso de los mundos.

La traducción de los Besos de Juan Gualberto González, cuarta española en el orden de publicación, que no de ejecución, constituye, en primer lugar, un nuevo paso para desenterrar del olvido a «ese poeta, flor de un día», en frase de Fernández Shaw, que fue Juan Segundo a quien, «a cambio de una vida muy corta, los hados te conceden un nombre eterno, y te arrancan del Elíseo para que no puedas sobrepasar a los antiguos y grandes poetas a quienes tú ya habías igualado en este tan reducido tiempo", cual figura en el epigrama que a la muerte del joven poeta dedicó Andrea Alciato según leemos en Iohannis Secvndi opera, accurate 
recognita ex Museo P. Scriverii (Lugdvni Batavorvm, Apud Franciscum Moyaert, 1651). Por otra parte, con el desempolvamiento de este manuscrito de cuya existencia da noticia Lomba y Pedraja en la obra, más arriba citada, El Padre Arolas, su vida y su poesía, queremos contribuir a un mayor conocimiento de un humanista español de quien Menéndez Pelayo dijo:

El nombre de este humanista excelente no es tan conocido como mereciera, dado el número, importancia y esmerada ejecución de sus versiones. Varón tan modesto como docto, jamás pensó en que las obras por él emprendidas para distracción y solaz de más graves tareas pudieran traspasar el breve y escogido círculo de sus amigos. Pero ni el bibliógrafo ni el historiador literario olvidarán que D. Juan Gualberto González, traductor egregio de la Poética de Horacio, de las Eglogas de Virgilio, Calpurnio y Nemesiano, de los Amores de Ovidio y de los Besos de Juan Segundo; autor de investigaciones ingeniosas y curiosos ensayos métricos, consumado filólogo, no ayuno de erudición helénica y con pocos rivales en la latina, brilló en la extinguida pléyada de entusiastas cultivadores de las letras clásicas con méritos no muy inferiores a los de Burgos, Hermosilla, Pérez de Camino, Castillo y Ayensa y otros varones doctos que en las primeras décadas del presente siglo consagraron sus tareas a trasladar a nuestra lengua aquellos vates de la antigüedad. (Biblioteca de Traductores Españoles, II, p. 144).

Por lo que respecta al mérito de esta traducción, sean nuestros lectores quienes juzguen de su bondad después de haber leído a Menéndez Pelayo, e independientemente del mismo. 


\section{Transcripción del manuscrito}

\section{Noticia de la vida y escritos de Juan Segundo II. Traducción española de los Besos}

\section{Noticia de la vida y escritos de Juan Segundo}

Entre los poetas latinos modernos goza muy distinguido lugar Juan Segundo. Nació en la capital de la Holanda en 1511. De edad de 18 años pasó a Brujas y allí tomó del célebre Alciato algunas lecciones de jurisprudencia hasta que, al fin disgustado de la aridez y escabrosidad de la ciencia, pasó a Italia ${ }^{1}$ y de allí a España donde fue secretario del Arzobispo de Toledo ${ }^{2}$ por cuyo consejo, según quieren algunos, siguió a Carlos Quinto en la jornada de Túnez.

La delicadeza de su temperamento le obligó a dejar España y vuelto a los Países-Bajos, murió en Utrec en la temprana edad de 25 años.

1 El Marqués de Morante, en su Biografía de Juan Segundo, dice: «Su viaje a Italia es quimérico, porque el mismo Juan Segundo nos ha dejado la relación de todos los viajes que hizo, y en ella no hay la menor alusión a éste. No hay tampoco tiempo en que pudiera emprenderlo, como no fuera entre el que hizo a Bourges y a España, como ya veremos después. Y con efecto, los que sostienen que fué a Italia, dicen que lo verificó antes de ir a España. Pero medió muy poco tiempo para que pudiera emprender semejante viaje, porque habiendo salido de Bourges para Malinas el 4 de marzo de 1533, no llegó a su patria hasta el 13 o el 17 del mismo mes. Consta además que estaba allí el 8 de mayo siguiente, y que el 28 de dicho mes emprendió su viaje a España. No pudo, pues, hacer el viaje a Italia en el tiempo que media desde el 17 de marzo al 8 de mayo, es decir, en el espacio de seis o siete semanas» (p. 6); y «Si Juan Segundo hubiera realizado el viaje a Italia, ¿cómo no había de habernos hecho una descripción de tan bello país el que en sus poesías elogia a otros países menos importantes?» (p. 11).

2 Juan de Tavera. 
Compuso gran número de elegías, silvas, epístolas ${ }^{3}$ y canciones fúnebres, obras en la mayor parte muy estimadas por la facilidad del lenguaje, gracia de estilo y belleza de composición. Solamente puede objetársele de haber en sus versos amorosos aventurado algunas frases que ya degeneran en licencia; y cierto que hubiera sido más honroso a su memoria y a su buen gusto si del todo las suprimiera ${ }^{4}$.

Entre sus producciones obtienen la preferencia Los 19 Besos. El autor de la Biblioteca de un hombre de gusto los califica diciendo que son como los primeros ímpetus de un alma llena de ternura, voluptuosa y apasionada. En efecto, sus imágenes son animadas, naturales y vivas; y sus descripciones, en que se ajustó más que Catulo (no es mucho decir) a las leyes de la honestidad, tanto más interesantes cuanto son la expresión sencilla y verdadera de su alma que sólo respira amores.

No tenemos traducción alguna en castellano ${ }^{5}$. En francés hay dos en prosa, de las cuales se dice que la primera hubiera sido más digna del original si a las buenas dotes de una prosa elegante y armoniosa acompañasen aquellas sensibilidad y belleza que tanto resaltan en el modelo. Y que la imitación que hizo Dorat en verso es, como la mayor parte de sus obras, más amanerada que natural, observándose que las imágenes más patéticas del amor se encuentran de ordinario como ahogadas en el exceso de los adornos y los conceptos alambicados.

Hay otra posterior a aquéllas, la cual anda con la de las elegías de Tibulo. Es del célebre Mirabeau, de la cual dice él mismo que es la más ajustada al original, y que si en ellas [sic] se observan algunas expresiones demasiado ardientes, culpa es sólo del poeta que, si bien holandés, escribe inspirado del amor y en el idioma armonioso del Lacio; lo cual le presta más energía y un salvoconducto para tomarse ciertas libertades. «La única, añade, que yo me he tomado es la de sostituir [sic] al nombre de su amada Neera el de Sofía; porque me hu-

3 Juan G. González, en nota, p. 2, del manuscrito: «Herrera en las anotaciones a Garcilaso, soneto 16 , cita la $11 .^{\text {a }}$ del lib. $2 .^{\circ}$ en que "trató della [de la artillería] en algunos versos, diciendo al fin dellos que el autor de este militar instrumento era más digno del rayo de Júpiter que de Salmoneon.

4 Hemos visto en la Introducción cómo Menéndez Pelayo aconsejaba una edición de pocos ejemplares.

5. En nota, p. 4, del manuscrito: «Hay imitaciones y pensamientos tomados del autor, como pueden verse en Meléndez las odas 23, 31 y 51 tom. $1 .^{\circ}$ (Madrid, 1820), en las cuales se ven reproducidos el plan y las ideas de los Besos $4 .^{\circ} 11 .^{\circ}$ y $19 .^{\circ}$ Después he visto una traducción en prosa, impresa en Córdoba (1834) la cual, a lo que recuerdo, es hecha de la francesa de Mirabeau, y no del original latino, conviniendo hasta en la sustitución del nombre de Neera con el de Sofía. Nota del Copiante». 
biera sido imposible dirigir a otra que a Sofía la copia de tan ardientes expresiones».

Yo he sostituido [sic] también el de Dórila: y no vaya a pensar el pío lector que es algún nombre disfrazado de persona real y verdadera: Honni soit qui mal y pense. No tengo, por desgracia, a quién dirigirme, sin que por eso me crea comprendido en la excomunión de una mujer célebre, la cual tenía por infeliz sobre todas las criaturas al diablo, porque no puede amar; sino que a mis amores, bien que andaluces y no holandeses, no les vinieran nunca bien las escenas ni las ansias que describe Juan Segundo, y rechazarian la dedicatoria; la cual ha de entenderse más antes con los amigos aficionados al ejercicio de traducir y de versificar, y mejor si anduvieran también «en la concha de Venus amarrados». En el nombre sostituido [sic] no hay otro misterio que el de venir a mi cuento, más que el de Neera, para los diversos géneros de metro que he adoptado, y poder variarlo, quedando el mismo sujeto, con el de Doris y con el esdrújulo Dórida, tan al caso para los asclepiadeos o anapésticos, de que hay abundancia en el original latino.

He procurado imitarlos en las composiciones en que el autor los emplea, desechando la traducción que ya había concluido en verso suelto, a fin de que suenen con el mismo compás que se siente al recitarlos en latín; punto de perfección a que debiera llegarse en otra clase de trabajos. Aun he tentado emplear el dístico latino en una pequeña muestra, y que pudiera haberse cultivado más por los sucesores de Villegas.

Esto cuanto a las formas: en lo que toca a la sustancia, como traductor, he procurado también acercarme todo lo posible al texto literal, conservando las mismas ideas, las mismas figuras y aun el giro de la frase: alguna vez ha sido quizá servilmente; en cambio de lo cual en otros lugares me he tomado la libertad de apartarme del texto cuando me pareció que ganaría el pensamiento sostituyéndole [sic] con otro del mismo espíritu, o con otra frase o giro más conforme a la índole de la lengua castellana, y aun al sentido lógico de la composición: éstos van notados con la señal + y espero que los inteligentes han de apreciar estas licencias, que no son en gran número. Y para los que no gustan (ni yo tampoco) de tanto besuqueo ni de tanta desnudez, hubiera yo trabajado como al final del Beso 12, en disfrazar con metáforas o con otras imágenes, principalmente el $5 .^{\circ}$, el $10 .^{\circ}$ y el $16 .^{\circ}$, si no temiese desfigurarlos del todo, y si no bastasen a disculparme los ejemplos de otros poetas originales, imitadores y traductores, con fama de castos y de filósofos, que se leen y andan con aplauso y recomendación de modelos en manos de la juventud estudiosa. Que bien pudiera yo también decir: «J'ai vu les moeurs de mon temps, et j'ai traduit les Baisers de Jean Second». 


\section{Los 19 Besos}

Cuando a la excelsa cumbre de Citera ${ }^{1}$ la madre del amor al niño Ascanio ${ }^{2}$ llevó dormido, púsole en un lecho de tiernas violetas, blancas rosas sembrando al derredor, y por el bosque suavísimos olores esparciendo. Renovósele entonces de su Adonis la antigua llama, y cunde por sus venas el no bien extinguido ardor ${ }^{3}$. ¡Oh cuántas, oh cuántas veces ${ }^{4}$ quiso enternecida lanzarse al cuello del amado nieto! ¡Oh cuántas dijo: tal Adonis era! Mas el reposo plácido temiendo ${ }^{5}$ turbar del niño, en las vecinas rosas mil besos estampó. Viéronse al punto desplegando sus cálices, sedientas de recibir el aura que la amante Diosa espiraba de sus dulces labios; cuantas rosas tocaba, tantos besos nacían de improviso, que a Dione ${ }^{6}$ tornaban el placer multiplicado. Mas ya la Diosa, de sus blancos cisnes

1 Citera. Isla del Peloponeso. Fue colonizada por los dorios, y administrada después, sucesivamente, por los espartanos, atenienses, macedonios y romanos. Su fama, en la antigüedad, se debe principalmente al santuario, que en ella se encontraba, dedicado a Venus Afrodita o Venus Urania.

2 Ascanio. Hijo de Eneas y de Creusa. Siguió a su padre a Italia; en el Lacio, bajo el nombre de Julio, fundó la ciudad de Alba Longa y dio lugar a la «gens» julia.

Menéndez Pelayo transcribe «amor».

4 Gómez de la Cortina transcribe: «... ioh cuántas / veces, oh cuántas quiso...».

5 Variante de Juan G. González: «Pero temiendo el plácido reposo».

6 Dione. Ninfa, hija de Urano y de la Tierra. De sus amores con Zeus nació Afrodita. 
llevada en raudo vuelo, de la tierra el globo inmensurable penetraba en sus ocultos senos la fecunda semilla de los besos derramando, cual nuevo Triptolemo ${ }^{7}$, y por tres veces una voz resonó jamás oída:

De aquí la mies feliz para el doliente mortal nació, de aquí la medicina bálsamo de mis males. Yo os saludo una y mil veces, besos regalados, de las que fecundó cándidas rosas Citeres con sus labios ${ }^{8}$ producidos; de esta mísera llama refrigerio yo soy vuestro cantor. Vuestros loores resonará mi lira en cuanto dure de las Nueve el honor y de Helicona ${ }^{9}$, en tanto que de Eneas y su amada estirpe en la memoria se gozare el retórico Amor, y en el idioma numeroso de Roma se explicare.

\section{El beso primero en verso de romance (segunda traducción)}

Cuando Venus llevó a Ascanio dormido a la alta Cytera púsole en un blando lecho de rosas y violetas. De blancas rosas esparce al derredor lluvia inmensa que de süaves olores todo aquel recinto llenan.

7 Triptolemo. Hijo de Celeo, rey de Eleusis y de Metanira. En agradecimiento a la hospitalidad que Deméter, diosa de la agricultura, había recibido en casa de Celeo, dio a Triptolemo un carro y unas espigas de trigo con el encargo de recorrer el mundo para dar a conocer a los hombres la agricultura.

Gómez de la Cortina transcribe «su labio».

9. Helicona. Se refiere al Helicón, monte muy arbolado de Beocia consagrado a las Musas, en el que se encuentran las fuentes de Aganipe y de Hipocrene, cuyas aguas provocaban la inspiración poética de cuantos las bebian. 
Allí entonces de su Adonis la llama se le renueva, y el ardor mal extinguido se difunde por sus venas. ¡Cuántas veces en sus brazos al nieto estrechar quisiera!, $\mathrm{y}$, icuántas enternecida dijo: tal Adonis era! ${ }^{10}$. Mas temiendo si al infante quizá sus besos despiertan, en las rosas los estampa que el florido lecho cercan.

Viéraslas tornar ansiosas su cáliz al aura lenta que la amante diosa espira de su linda boca. Vieras cuantas rosas ella toca tantos besos nacer de ellas de que la diosa recibe multiplicada cosecha. Mas ya en sus cándidos cisnes con raudo vuelo se eleva por el éter circuyendo los ámbitos de la tierra. Y cual nuevo Triptolemo ${ }^{11}$ la semilla esparce nueva y tres veces nunca oída fatídica voz resuena.

De aquí nació para el triste mortal la feliz cosecha, de aquí el bálsamo süave medicina de mis penas.

Yo os saludo, amables Besos de las rosas que Citera ${ }^{12}$ humedeció producidos, solaz único en mis penas.

11 Ver nota 7.

12 Ver nota 1. 
De vuestras glorias mi lira

resonará en cuanto sea

célebre la doble cima

de Helicón y las Camenas ${ }^{13}$.

En cuanto el amor se goce

con la estirpe de su Eneas

$\mathrm{y}$ en los númenes ${ }^{14}$ se explique

de su dulcísima lengua.

\section{II}

Como la vid al álamo vecino lasciva yedra al encumbrado roble con sus inmensos brazos retorcida estrechan amorosos;

así mi cuello estrecha con los tuyos:

que yo a tu cuello en sempiterno lazo, besándote sin fin, Dórila bella, quiero ceñir los míos.

$\mathrm{Ni}$ los dones de Baco amigo entonces ni los de Ceres ${ }^{15}$ fueran poderosos ni el regalado sueño a distraerme de tu rosada boca.

Sino que en mutuos besos juntamente espirando los dos la misma barca nuestras almas amantes llevaría a la mansión de Dites.

De allí cruzando por amenos valles y odoríferos campos donde reina perpetua primavera, al venturoso lugar aportarían, donde los héroes en amor insignes, por siempre a sus amadas reunidos, cantan himnos alegres, alternando con la festiva danza.

Gómez de la Cortina transcribe: «De Helicón con sus Camenas». Las Camenas eran ninfas de la antigua Italia, identificadas más tarde con las Musas griegas. Camenae significa «diosas de los encantamientos», por lo que, con el tiempo, se les llegó a atribuir el poder despertar el sentido de la adivinación, llegando de esta forma a convertirse en diosas de la poesía.

Gómez de la Cortina transcribe «números». 


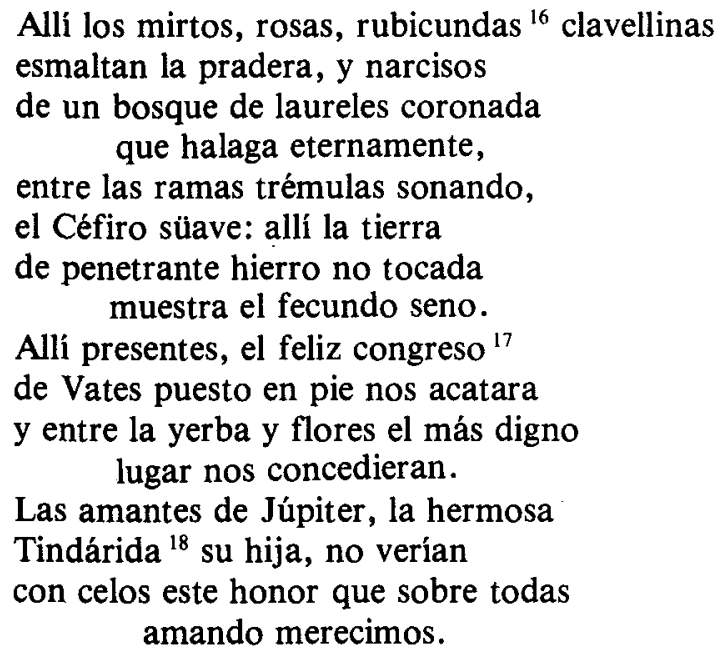

\section{III}

¿Por qué tantos desvíos?

Un beso pido, hermosa;

que ahora apenas hiciste

más que allegar tus labios a los míos ${ }^{19}$.

Después, como quien toca

con planta temerosa

serpiente venenosa,

amedrentada huiste,

tu boca retirando de mi boca,

y eso no es beso, Doris; no es, tirana,

dar de comer, sino excitar la gana.

16 Este verso no da la medida, o porque no fue revisado por el autor, o porque el copista cometió error de transcripción.

Variante de Juan G. González: «la dichosa turba».

18 Tindárida. Es Helena, hija de Zeus y de Leda, la esposa de Tíndaro, de quien se había enamorado el dios del Olimpo, el cual, para conseguirla, tomó la forma de Cisne. Helena fue raptada por Paris, rapto que provocó la guerra de Troya.

19 Variante de Juan G. González: «ese tu labio al mío». 
[Otra traducción de este mismo beso]

¿Por qué tantos desvíos?

Dame, Dórila, un beso, que no hiciste con ese que me diste

sino llegar tus labios a los míos.

Después como el que toca

inopinadamente

mortifera serpiente

amedrentada huiste,

tu boca retirando de mi boca.

$\mathrm{Y}$ eso no es un beso en regla; no es, tirana, dar de comer, sino excitar la gana.

Proyecto de traducción del Beso $3{ }^{\circ}$ en dísticos

Dame, Dórila, un beso: tan sólo un beso, tirana que ahora llegaste apenas ese tu labio al mío.

Después, cual si de súbito hubiera frígida sierpe tu planta hollado, huyes despavorida.

Y eso no es beso, digo; no es eso, luz de mis ojos, dar de comer, Dorila; sino excitar la gana.

Dame, Dórida [sic], un beso: tan sólo un beso, taimada: que ahora llegaste apenas ese tu labio al mío.

Después, como el que súbito, si oyó mortífera sierpe, retrocede espantado: torces [sic] el rostro esquiva.

De mí tu labio apartas; y eso no es beso: no es eso dar de comer, Dórila, sino excitar la gana.

El mismo. Anacrióntica [sic]

Dame un beso, uno solo que en ése no hubo, Anarda, sino allegar al mío tu labio de pasada. Y después cual si hubieras tal vez hollado incauta mortífera serpiente huyes amedrentada. Tu labio me retiras $Y$ eso no es beso, ingrata; dar de comer no es eso, sino excitar la gana. 
No da besos Dorila, que da néctar, da al ánima suavísimos olores de cinamomo y nardo y de tomillo y miel, cual del Himeto ${ }^{20}$ en los collados liba la abeja en las cecropias ${ }^{21}$ rosas y lleva luego a las virgíneas celdas de las tejidas mimbres defendidas. Que si muchos me diese, al punto mismo me hicieran inmortal, y con los Dioses tuviera asiento en la celeste mesa. Mas ten allá, Dorila, tus halagos, guarda tus dulces besos, o conmigo ven a ser inmortal; que yo no quiero gozar sin ti de la celeste mesa. No, aunque los dioses, Jove destronado, el cetro me ofreciesen del Olimpo.

\section{$\mathbf{V}$}

Cuando en tus brazos cándidos me estrechas, Dorila hermosa, y a mi cuello asida tu seno y rostro inclinas sobre el mío, acá y allá meciéndote:

que a mis labios los tuyos allegando, con süaves mordiscos acometes, y en justa pena vuelves de los míos lastimada quejándote;

cuando tu lengua trémula, vibrando a un lado y a otro lucha con mi lengua, de aquel humor suave que destilan las dos saboreándose; que, yo aspirando de tu blando aliento el aroma divino, delicioso, refrigerio, sustento, prenda amada, de ésta mi vida misma; sus canteras de mármol. ternas, de la familia de las moráceas. Aquí está usado como adjetivo determinante de rosas. 
al ánima que ya desfallecida

del excesivo ardor que lentamente

mi pecho iba extenuando y consumiendo

los vitales espíritus,

tú, bella Doris, con el aura leve

de tu divino aliento rëanimas

moderando el ardor que penetraba

mi pecho hasta las médulas.

iOh grato refrigerio!, digo entonces;

ioh ya extinguida venturosa llama!,

y, Amor, exclamo; Amor es solamente

el númen de los númenes,

y de los dioses no hay amor ninguno

y si alguno mayor, o dios o diosa,

deidad hay por ventura, ser no puede

otra que tú, mi Dórila.

VI

En dos mil besos, Dorila

de los más saboreados

fue el trato ayer: mil me diste,

tu has recibido otos tantos.

Llevaste el número, prenda.

Confiésolo; pero, ¿cuándo

en cuentas de amor has visto

andar con tanto más cuanto?

Quien las espigas contase,

¿alabaría un sembrado?

$\mathrm{Y}$ contadas, ¿serán muchas,

me di, las flores de un campo?

¿Quién jamás por mil racimos

te hizo votos, padre Baco?

$\mathrm{Ni}$ a ti, dios de las florestas,

por mil panales contados ${ }^{22}$.

Cuando Júpiter piadoso

manda su rocío grato

al mustio valle, las gotas

que han caído ${ }^{23}$ no contamos.

Para Gómez de la Cortina, este verso y el anterior son también una interrogación expresada así con el correspondiente signo de puntuación.

Gómez de la Cortina transcribe «cayeron». 


\begin{abstract}
Así también cuando el fiero

Bóreas ${ }^{24}$ el aire agitado ${ }^{25}$ brama horrendo, e iracundo empuña Jove sus rayos, manda confuso el granizo, cielo y tierra conturbando, $\mathrm{ni}^{26}$ sabe cuántas comarcas destruye y cuántos sembrados. Que a la majestad del númen, de los dioses soberana ${ }^{27}$, conviene así; en abundancia mandar todo, bueno y malo. Y tú siendo diosa, y diosa más bella de la que trajo ${ }^{28}$ el mar en la vaga concha por senderos azulados, los besos, celestes dones, me vas, cruel, descontando; pero no mis tristes ayes ni mis gemidos amargos. No las lágrimas que siempre cual torrente derramado se desprenden de mis ojos el rostro y pecho inundando. Pon mis lágrimas en data, pon tus versos ${ }^{29}$ en el cargo, rebaja dellos los míos, y verás cuánto te alcanzo.
\end{abstract}

24 Bóreas. Dios griego del viento norte y de las tormentas, hijo de Eos, la Aurora, y de Astreo, el Cielo estrellado.

25 Gómez de la Cortina transcribe «agitando».

26 Menéndez Pelayo transcribe «no».

27 Gómez de la Cortina transcribe «soberano».

28 Menéndez Pelayo transcribe «que la».

29 Gómez de la Cortina transcribe «besos». 
Lágrimas innumerables son las que por ti derramo:

dame sin número besos, y cuenta nueva con pago. ${ }^{30}$

\section{VII}

Cien besos cien veces mil veces cien besos, de besos mil miles, y tantos mil cuentos como gotas de agua tiene el mar inmenso, arenas la playa, estrellas el cielo; en tu linda boca, locuaces ojuelos, purpúreas mejillas y cándido seno ${ }^{31}$, hermosa Dorila, te diera yo arreo ${ }^{32}$, todos de seguida, sin tomar aliento. Sí, Dórila hermosa; pero tiene un pero: que vecino tanto al cándido seno ${ }^{33}$, a tu labio rojo ${ }^{34}$, locuaces ojuelos, mejillas de rosa estoy cuando beso; que ver no es posible ni el cándido seno ${ }^{35}$,

Menéndez Pelayo pone puntos suspensivos $(\ldots)$ tras la conjuncion $\not$.

Gómez de la Cortina transcribe «túrgido seno».

Arreo. Aqui es adverbio de modo y significa "sucesivamente, sin interrupción».

Ver nota 31.

34

Gómez de la Cortina transcribe «tus labios rojos».

35 Ver nota 31. 


rosadas mejillas,
locuaces ojuelos.
Ni la blanda risa
con que cual el velo
de la parda nube
disipa el sol bello,
y en su coche de oro ${ }^{36}$
el puro sereno ${ }^{37}$
corre, de su lumbre
los orbes hinchendo;
también tú, sol mío ${ }^{38}$,
destierras acerbos
suspiros del alma,
cuidados del pecho.
Mis ojos y labios,
ipor qué tan opuestos?
Si beso, no miro;
si miro, no beso.
Más quisiera a Jove
de rival perpetuo:
pugna entre mis ojos
y labios no quiero.
Riyose Dórila,
y díjome, necio,
retírate un poco
entre beso y beso. ${ }^{39}$

Menéndez Pelayo transcribe «carro de oro».

Ibídem, «paso sereno».

38

Juan G. González ofrece de éste y de los inmediatos anteriores versos la variante siguiente:

$$
\begin{aligned}
& \text { «disipa el sol bello } \\
& \text { cuando en su carroza } \\
& \text { el puro sereno } \\
& \text { corre, de su lumbre } \\
& \text { los orbes hinchendo; } \\
& \text { tú, sol de mis ojos». }
\end{aligned}
$$

39 Ibídem, en nota, p. 38, del manuscrito: «Añadido para ajustar las paces partiendo la diferencia ya que no le ocurrió al buen Holandés, aunque tan práctico en la materia». El Marqués de Morante dice «autor» en lugar de «buen Holandés», y Menéndez Pelayo, "Añadidos estos cuatro versos» por «Añadido», y «no se le» por «no le». 


\section{VIII}

¿Qué furor te ha llevado, Dórila, amada prenda, con feroces mordiscos a destrozar mi lengua? ¿Acaso no bastaban las heridas sangrientas que hizo Amor en mi pecho con sus agudas flechas? ¿Sino también quisiste llevar tu vïolencia hasta clavar los dientes en mi inocente lengua? ¿La que al alba, al sol puesto, y mil noches acerbas, y mil amargos días cantaba tu belleza? Ésta, si no lo sabes, joh tirana!, es aquella que del rubio cabello las ondulantes hebras, tus ojuelos alegres, tu cuello de azucena y el seno de alabastro de continuo celebra, la que tu nombre amado elevó a las estrellas del polo ingrato a Jove a la zona desierta, donde mis blandos versos fama te den eterna, porque fuiste mi gloria, mi delicia, mi prenda, mi cándida paloma, mi tesoro, mi tierna tortolilla, mi Venus con harta envidia de ella. Acaso fue de industria extendiendo, soberbia, que sin lesión alguna sin el furor que engendra, nunca debidamente yo celebrar pudiera 
los ojillos parleros

y el cuello de azucena, y los purpúreos labios

y las doradas trenzas

$\mathrm{y}$ aun el acerbo diente, que yo llamaba perla.

«Cante sí, balbuciente, con furor el poeta», así dijiste. ¡Oh vano poder de la belleza!

\section{IX}

No siempre muchos, ni humecidos [sic]

del que sabroso tu linda boca

licor destila, me des los besos:

ni con tu risa mezclados vengan,

ni moribunda sobre mi cuello

tu rostro inclines. Sin la discreta

justa medida, las cosas dulces

el alma enervan y tristemente

tocan el límite ya del fastidio.

Cuando te pida yo besos nueve, rebaja siete: dos sólo quiero, rápidos ambos, no de los óptimos

humedecidos del que entre perlas

licor destila tu linda boca.

De aquellos, digo, que da al telígero ${ }^{40}$

Cintio su hermano la casta Diana, de los que al padre da honesta virgen

de amor impúdico no sabidora.

Tú que lo eras, evita luego

como los dieres la vista mía:

y a los recónditos ángulos íntimos

luego a esconderte con pie ligero.

Allí alcanzándote, de aquestas manos

verás la fuerza y el señorío.

En ti cautiva he de lanzarme

como en su presa cazador férvido,

40 Telígero. Neologismo construido sobre telum «arma arrojadiza», y gero, «llevar, portar», el cual referido a Apolo, llamado aquí Cintio por el lugar donde nació, significa «portador de armas, de flechas», ya que, como se sabe, Apolo es también el dios de los arqueros. 
y halcón altivo de corvas uñas en la indefensa paloma tímida. Tú suplicante, las manos cándidas humildemente pondrás tendidas: luego, colgada del cuello mío, los siete besos que me negaras condicionados querrás pagármelos. Te engañas, mísera; que no se paga ni con el séptuplo tanta malicia. Yo de mis brazos porque no huyas, al cuello inhiesto haré cadena, hasta que, absueltos los besos todos, jures por todas las gracias tuyas que por tal crimen la misma pena mil y mil veces llevar quisieras.

\section{$\mathbf{X}$}

No sé qué especie de besos me sientan mejor: me cuadran los que en mi boca la tuya humedecidos estampa. También los rápidos, secos, tienen para mí su gracia: su calor templado suele penetrar a las entrañas con los que, puestos en blanco tus ojuelos, me regalas, tósigo y bálsamo a un tiempo el mal que hicieran lo sanan. Si tus mejillas de rosas, si tu cándida garganta y tus hombros y tu seno sobre los míos descansan, en tus mejillas de rosa, tus hombros, seno y garganta huelgo de ver de mis besos allí la lívida estampa. O si con trémulo labio, lengua con lengua trabada, extraes el humor, en una confundiéndose dos almas, y a cada cuerpo, no suyo, una y otra se trasladan; 
cuando amor está ya dando

las últimas boqueadas, todos los besos, pausados, breves, lánguidos me agradan; ya les dé, ya los reciba de tu boca resalada.

Mas tus besos con los míos no han de tener semejanza: cada cual de su manera ha de usar, siempre variada. $\mathrm{Y}$ si no acertare alguno en su vez a variarla, sea esta ley por ambas partes rígidamente observada. Que la vencida, ella sola tantos y en maneras tantas dé a la otra, como dieron $y$ recibieron entrambas.

\section{XI}

Dicen que besos canto lascivos, deshonestos, cual nunca nuestros padres adustos conocieron. Cuando yo entre mis brazos, vida hermosa, te tengo y absorto en tus caricias muertecito me quedo, cuando estoy de manera que ni oigo, ni veo, ¿lo que de mí se diga ha de tenerme inquieto? Riyóseme Dórila, oyendo decir esto, y con sus bellos brazos ciñóme en torno al cuello, y estrechamente unida conmigo, me dio un beso, que mejor nunca Marte lo recibió de Venus. $Y$ díjome: no temas los juïcios severos del vulgo, que esta causa toca sólo a mi fuero. 


\title{
XII
}

\author{
¿Por qué ese ceño, matronas púdicas, \\ vírgenes castas? No canto anécdotas \\ de dioses lúbricos, ni vuestros ojos \\ verán imágenes aquí de escándalo. \\ No hallarán cláusula que a sus discípulos \\ inocentillos mostrar no puedan [sic] \\ dómine rígido desde la cátedra. \\ Casto ministro del coro Aonio ${ }^{41}$, \\ yo sólo canto besos purísimos. \\ ¿Y las matronas y castas vírgenes \\ tuercen el rostro! Acaso, ¡imbéciles!, \\ del libro el rótulo pudo asustarlas \\ y algún epíteto menos devoto \\ que en tanto número pudo escapárseme. \\ Id de aquí lejos, turba selvática, \\ matronas rígidas, vírgenes párvulas. \\ ¡Cuánto más púdica mi bella Dórila, \\ cuando mis besos yo recitándola, \\ tiñe de púrpura su rostro cándido, \\ y cual vosotras también lo tuerce \\ vergonzosilla..., como diciéndome, \\ bien los recitas; hora [sic] estámpalos.
}

\section{XIII $^{42}$}

Lánguido yo, rendido

después de una campaña

amorosa yacía, yo al tuyo y tú a mi seno recostada.

Todo en mis secos labios

el aire que alentaba

consunto, mal pudiera

dar refrigerio nuevo a mis entrañas.

41 Aonio. Hijo de Poseidón y antiguo rey de Beocia. De él toma nombre el pueblo de los ánoes, y la parte del país situada en los confines de la Fócida, llamada Aonia. En esta región se encontraba la fuente de Aganipe (ver nota 9), razón por la cual las Musas eran llamadas también Aonides, o Aoniae sorores. número al texto latino. 
Ya el Estigio y la triste mansión, al sol negada, ante mis ojos vía y del viejo Carón la negra barca. Cuando mis secos labios tú con el aura blanda de un beso refrescastes [sic] ${ }^{43}$ arrancado de lo íntimo del alma.

Beso que a retraerme bastó de la morada tenebrosa de Pluto, y que el viejo Carón sin mí remara.

Dije mal: no va solo remando con su lancha ${ }^{44}$, a los flébiles manes navegando mi sombra va liviana, sino que en este cuerpo vive parte del alma tuya, mi bien, y el tuyo ${ }^{45}$ que iba ya deslizándose afianza. Mas, con todo impaciente la mezquina se afana por desasirse, $y$ triste sigue la vía de la oscura estancia. Que si el remedio usado, de un beso tuyo el aura, no la conforta, el nudo romperá al fin que ya se deslizaba. Pues aplica a los míos tus labios, adorada, que siempre un mismo aliento reparador aspiren nuestras almas. Hasta que al fin, Dorila, ya de gozar cansadas, si bien no satisfechas, con los dos cuerpos se confundan ambas.

43 Gómez de la Cortina transcribe «refrescaste», y Menéndez Pelayo, «refrescante».

44 Menéndez Pelayo transcribe «barca».

45 Gómez de la Cortina transcribe «nudo». 


\title{
XIV
}

\author{
¿A qué me presentas \\ tu purpúreo labio, \\ ingrata Dorila, \\ dura más que el mármol? \\ Besarte no quiero \\ que tus besos hallo \\ insípidos, tristes, \\ tímidos, forzados. \\ Con ellos furioso, \\ en deseos vanos \\ todo me consumo \\ y mísero ardo. \\ ¿Huyes? Mas no, espera: \\ no me sean negados \\ esos tus ojuelos, \\ ni el purpúreo labio. \\ Ya quiero besarte, \\ dura más que el mármol... \\ Ay, no; que es muy más blanda que plumilla \\ blanda de blando cisne mi Dorila.
}

\section{XV}

Medía ya la puntería y a la sien el arco abrazado iba a lanzar, bella Doris, Amor contra ti su dardo. Mas vio la frente y en ella los cabellos derramados $\mathrm{y}$ tus inquietos ojuelos amores centelleando. Vio tus rosadas mejillas, y la risa de tus labios y ese, de su madre envidia, vio tu seno de alabastro. De sus manos ternezuelas cayéronsele los dardos, y dando una carrerilla, fue a posar en tu regazo. $\mathrm{Y}$ en tus mejillas de rosa $\mathrm{y}$ en tu seno $\mathrm{y}$ en tus labios estampó mil dulces besos 
de mil modos variados, que a lo interior de tu pecho el aroma deslizaron de los mirtos y el süave licor de Chipre ${ }^{46}$ y de Pafos ${ }^{47}$, y por su madre juraba, y por los númenes altos que nunca, nunca sus flechas asestaría en tu daño.

De aquí procede el aroma de tus besos y el encanto, y el rigor, no es maravilla, de ese tu pecho de mármol.

\section{XVI}

Dórida [sic] bella más que la cándida lumbre de Cintia, más que la estrella de Venus áurea; hermosa, dame dame cien besos.

Cuantos al ávido vate dio Lesbia, de él recibidos; cuantos amores en tu purpúreo labio revuelan, $\mathrm{y}$ en tus mejillas. Cuantas evitan $\dot{y}$ dan tus ojos vidas o muertes, cuantos temores dan y esperanzas, cuantos amantes por ti suspiran.

Cuantas säetas en este pecho lanzó mortíferas la dura mano del dios alígero; cuantas reserva su aljaba de oro. Con ellos vengan la grata risa, con todo el séquito de los halagos, blandos murmurios, palabras dísticas, cios que la colonizaron. Su clima y producciones son de tipo mediterráneo. honor de Venus (Astarté). 
leves mordiscos.

Así arrullándose dos tortolillas ${ }^{48}$

con sus picuelos alternan, cuando

al primer hálito de los Favonios ${ }^{49}$

ceden los Áfricos.

Tú reclinándome ${ }^{50}$ contra mi seno, perdida, exánime, tus luces lánguidas puestas en blanco, dirás estréchame, que yo fallezco.

$\mathrm{Y}$ entre mis brazos yo comprimiéndote, y al tuyo frígido mi seno cándido, con el espíritu de un largo beso te daré vida.

Hasta que exhausto yo con el beso tan prolongado, perdido, exánime, caiga en tus brazos, también pidiéndote que me sostengas.

Y entre tus brazos, así estrechándome, y al tuyo cálido mi seno frígido, con el espíritu de un largo beso me darás vida.

Así gocemos, mi bien, unidos, la edad florida, antes que pálida vejez nos traiga cuidados míseros, cuitas y muerte.

\section{XVII}

Cual rosa del aljófar ${ }^{51}$ cristalino

de la noche bañada, al primer rayo

del sol despliega su color purpúreo;

Variante de Juan G. González: «amantes tórtolas así arrullándose».

Favonios. Los vientos eran cuatro coincidiendo, por su procedencia, con los puntos cardinales: 1) el Noto o Austro, del Sur; 2) el Bóreas (ver nota 24), del Norte; 3) el Céfiro o Favonio, del Oeste; 4) el Euro o Vulturno, del Este. Junto a estos cuatro principales se conocen también otros secundarios entre los que señalamos el Áfrico procedente de la región intermedia entre el Austro y el Favonio.

Debiera decir «reclinándote».

51 Aljófar. Entre las acepciones de este término: «perla, o conjunto de perlas, pequeñas y de forma irregular», y "gota de rocío», está tomado aquí según el último significado. 
así los labios de mi ninfa bella amanecen después que en prolongada noche feliz del néctar de mis besos regados fueron: el carmín realza la nieve de su rostro, cual si viste clavel ardiente en blanca mano y pura.

Así aparece la cereza nueva en la vestida rama cuando mayo cede sus galas al estío ¿Por qué, iay triste! ${ }^{2}$ cuando recibo de tu linda boca tan resalados besos, de tu lecho es forzoso partir? Al menos guarda, guárdame, hermosa niña, de tus labios el matiz suavísimo hasta tanto que la callada noche a ti me vuelva. Mas si de un otro besos recibieren, al mismo tiempo pálidos se tornen cual amanecen las mejillas mías.

\section{XVIII}

Cuentan que Venus viendo los labios de mi adorada, cerco brevísimo que en su figura releva cándida, cual busto ebúrneo donde curiosa mano engastase corales nítidos, bañada en lágrimas así convoca sus Amorcillos, y lamentándose, ¿qué sirve, díjoles, si por sentencia de un pastorcillo, de mis purpúreos labios en Ida como las otras diosas rivales fue la victoria? ¿Si por sentencia ya de ese vate vencida quedo de una tal Dórida? Id a ese réprobo, y de mortiferos dardos la aljaba bien abastada, en lo más hondo del tierno pecho fieros lanzádselos; que al despedírselos, con gran estrépito retiemble el arco. error de transcripción. 
Mas sus ardores ella no sienta:

frígida flecha de plomo alcánzela, y que a sus venas consumiéndose, lleve su inercia súbito hielo.

Así fue, Dórida: hasta las médulas penetró el fuego de que son pábulo ya mis entrañas. Tú circuida de hielos ásperos el pecho indómito, como a los ímpetus del Adria horrísonos o del mar Sículo roca firmísima, segura ríes, y este tu amante de haber loado tu labio rojo sufre la pena ¡Ay!, que no sabes, mísera Dórida, por qué desamas, ni cuánto puedan, o de los númenes, o de Cyprina las iras émulas.

Pon la soberbia, y al rostro plácido de hoy más conformes sean tus propósitos. Llega esos tus labios dulcísimos, de mis dolores causa inocente, a estos mis labios, con que extrayéndome parte del tósigo de que son pábulo ya mis entrañas, en amorosa llama recíproca ardas y goces conmigo a un tiempo; y tú a los númenes ni a Venus temas que a las hermosas los mismos dioses rinden su cetro.

\section{XIX}

¿Por qué en las purpúreas rosas

$y$ en el tomillo, abejillas, y en la temprana violeta la miel libáis todavía? ¿Por qué al eneldo oloroso $\mathrm{y}$ al narciso, simplecillas, revoláis? Todas al labio venid de la prenda mía, que ella sola del tomillo y de las rosas espira, del jacinto y vïoleta el aroma y ambrosía. 
Del eneldo se difunde

lejos el aura benigna

con el verdadero llanto

de Narciso humedecida.

Bañada también la sangre

de Jacinto, con la misma

brillantez que ambos licores

cuando cayeron tenían, cuando del etéreo néctar

y aire puro confingida,

se esparció por todo el suelo

de las flores la semilla.

Mas no me neguéis, ingratas, de aquella su boca linda

libar la miel; que por socio

me toca una partecita.

$\mathrm{Ni}$ avaras querréis tampoco

colmadas vuestras celdillas

tener siempre; porque entonces

sus labios se agotarían.

$Y$ refrigerio no hallara

más la pena merecida

por revelar el secreto

en ellos la boca mía.

Y guardaos bien de ofenderla con vuestra flecha maligna, que agudas, más y mayores

de sus ojos ella vibra.

$Y$ cierto que sin venganza

nunca dejará la herida.

Llegaos y blandamente

libad la miel, abejillas. 